\title{
Acute effects of two different doses of magnesium sulphate in infants with birth asphyxia
}

Division of Paediatrics and Child Health, University of Leeds, The General Infirmary at Leeds

$M$ Levene

R Hartley

Department of Paediatrics,

Karolinska Hospital, Stockholm, Sweden M Blennow

Department of Paediatrics, Aker University Hospital, Oslo, Norway

A Whitelaw

E Hanke

Children's Hospital, University of Helsinki, Helsinki, Finland

V Fellman

Correspondence to: Professor M I Levene, Division of Paediatrics and Child Health, Clarendon Wing, The General Infirmary at Leeds, Leeds.

Accepted 24 July 1995

\author{
M Levene, M Blennow, A Whitelaw, E Hankø, V Fellman, R Hartley
}

\begin{abstract}
The effects of two different doses of

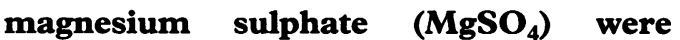
evaluated in a group of 15 full term infants with Apgar scores of $<6$ at 10 minutes, studied within 12 hours of delivery. Seven infants received $400 \mathrm{mg} / \mathrm{kg} \mathrm{MgSO}_{4}$ and eight received $250 \mathrm{mg} / \mathrm{kg}$. After the larger dose, mean arterial pressure (MAP) fell by a mean of $6 \mathrm{~mm} \mathrm{Hg}(13 \%)$ at one hour but was not significantly reduced thereafter. Respiratory depression lasted three to six hours. EEG readings and heart rate were not significantly different. Mean serum $\mathrm{Mg}^{2+}$ increased from 0.79 to 3.6 $\mathrm{mmol} / \mathrm{h}$ at one hour. After $250 \mathrm{mg} / \mathrm{kg}$ $\mathrm{MgSO}_{4}, \mathrm{MAP}, \mathrm{EEG}$, tone and heart rate were unchanged. One infant developed transient respiratory depression. Mean serum $\mathrm{Mg}^{2+}$ rose from 0.71 to $2.42 \mathrm{mmol} / \mathrm{l}$ at one hour. $\mathrm{MgSO}_{4}(400 \mathrm{mg} / \mathrm{kg})$ has an unacceptable risk of hypotension; $250 \mathrm{mg} / \mathrm{kg} \mathrm{MgSO}_{4}$ was not associated with hypotension although respiratory depression can occur.

(Arch Dis Child 1995; 73: F174-F177)
\end{abstract}

Keywords: hypoxia-ischaemia, magnesium, pharmocokinetics, blood pressure.

Hypoxic-ischaemic encephalopathy following acute intrapartum asphyxia remains a significant cause of severe neurological disability. Among full term infants, about 1 in 1000 die or are severely disabled as a result of this condition. ${ }^{1-4}$ Some children also survive asphyxia with minor or moderate learning difficulties, and these are potentially avoidable. ${ }^{56}$ No treatment for birth asphyxia or hypoxicischaemic encephalopathy has been shown to improve clinical outcome. ${ }^{4}$

An acute hypoxic-ischaemic insult initiates a cascade of biochemical events which lead, over the course of hours or even days, to irreversible neuronal injury. Neuronal injury is caused in part by excessive release and reduced uptake of glutamate. ${ }^{7}$ Glutamate mediates fast excitatory synaptic transmission and acts at specific receptor sites on cell bodies and post-synaptic dendrites. These receptors are classified according to specific ligands which bind them. It is thought that the $\mathrm{N}$-methyl-D-aspartate (NMDA) receptor is particularly important in the development of post-asphyxial neuronal injury. High concentrations of glutamate cause the NMDA channels to open, allowing excessive amounts of calcium into the neurone, inducing irreversible cell injury. The immature brain may be particularly vulnerable to the effects of excessive glutamate release as there is a far greater proportion of NMDA receptor sites in both the immature rat brain cortex and the developing human brain compared with the adult brain of the same species. ${ }^{8-10}$ Several drugs can antagonise the NMDA receptor. In particular, MK-801, when given after a hypoxic insult to the immature rat brain, affords impressive neuroprotection. ${ }^{11}$ Unfortunately, MK-801 is potentially toxic and its use in human infants is not recommended.

Magnesium ions gate the NMDA channel in a voltage dependent manner by producing hyperpolarisation, and increasing the extracellular $\mathrm{Mg}^{2+}$ concentration may protect the brain from NMDA receptor mediated damage. The neuroprotective effect of $\mathbf{M g}^{++}$has been evaluated in a neonatal rat model and a single dose of $2 \mathrm{mmol} / \mathrm{kg} 15$ minutes after an NMDA insult significantly reduces the severity of brain injury. ${ }^{12}$ This effect was even greater when higher or multiple doses of magnesium sulphate were used. It has also been shown that a combination of magnesium sulphate $\left(\mathrm{MgSO}_{4}\right)$, methionine, and mannitol given 15 minutes after hypoxia-ischaemia in 8 day old rats, reduced the extent of neuropathological damage. ${ }^{13} \mathrm{MgSO}_{4}$ also seems to have a central anticonvulsant effect on hippocampal seizures ${ }^{14}$ and can cause cerebral vasodilatation. ${ }^{15}$

$\mathrm{MgSO}_{4}$ has been widely used in obstetric practice for over 60 years. ${ }^{13}$ Its indications include suppression of preterm labour and management of pregnancy induced hypertension $-\mathrm{Mg}^{2+}$ has a vasodilator effect. $\mathrm{Mg}^{2+}$ readily transfers across the placenta. Lipsitz reported that maternal treatment with $\mathrm{MgSO}_{4}$ led to a mean maternal serum $\mathrm{Mg}$ concentration of $2.5 \mathrm{mmol} / \mathrm{l}$ and mean cord serum $\mathrm{Mg}^{2+}$ of $2.4 \mathrm{mmol} / 1 .{ }^{16}$ Many of the infants showed flaccidity, hyporeflexia, and had a weak cry. Normally, cerebrospinal fluid $\mathbf{M g}^{2+}$ is maintained about $30 \%$ higher than the serum concentration by an active pump. ${ }^{17}$ It has been calculated that an increase in extracellular $\mathrm{Mg}^{2+}$ of 0.5 to $1.0 \mathrm{mmol} / \mathrm{l}$ is enough to effect synaptic and neuronal activity. ${ }^{18}$ Hypermagnesaemia can affect the peripheral nervous system by releasing acetylcholine and reducing the responsiveness of the postsynaptic muscle membrane. Paralysis of voluntary muscles has been reported at plasma $\mathrm{Mg}^{2+}$ concentrations above $5 \mathrm{mmol} / \mathrm{l} .^{19}$

To plan a study evaluating the effectiveness of $\mathrm{MgSO}_{4}$ as cerebral protection, it is important to perform a phase 1 study on (a) the pharmacokinetics of $\mathrm{MgSO}_{4}$ in asphyxiated infants and (b) the effect of high dose intravenous $\mathrm{MgSO}_{4}$ on physiological functions such as blood pressure, heart rate, respiration 
and neurological function. We planned a study to obtain this information, and a comparison of two different doses.'

\section{Methods}

Infants were eligible for the study if:

(a) gestation was equal to or greater than 35 weeks;

(b) postnatal age was less than 12 hours;

(c) major congenital malformations were absent;

(d) 10 minute Apgar score was less than 6, or 5 minute Apgar score was less than 6, together with evidence of fetal distress defined as any of the following: sustained episodes of fetal bradycardia $<100 /$ minutes, thick meconium stained liquor, scalp $\mathrm{pH}$ of $<7 \cdot 11$, or umbilical arterial $\mathrm{pH}$ of $<7.00$ or umbilical base deficit greater than $-10 \mathrm{mmol} / \mathrm{l}$;

(e) the parent(s) gave informed consent to $\mathrm{MgSO}_{4}$ administration.

One infant was included on the basis of respiratory arrest with profound hypoxaemia and acidosis at 5 hours of age. Five collaborating European neonatologists agreed at the start of the study to use two different dose regimens for $\mathrm{MgSO}_{4}$. In two centres $250 \mathrm{mg} / \mathrm{kg} \mathrm{MgSO}_{4}$ was given intravenously over 10 minutes. In three centres $400 \mathrm{mg} / \mathrm{kg} \mathrm{MgSO}_{4}$ was given intravenously over 10-30 minutes.

Before the infusion of $\mathrm{MgSO}_{4}$ a continuous EEG (Oxford Medilog) or cerebral function monitor (CFM, Lectromed) recording was started. The following measurements were documented one hour before, immediately before, and one, three, six, 12, and 24 hours after the $\mathrm{MgSO}_{4}$ infusion. Mean arterial pressure (MAP) was measured by a transducer attached to an umbilical or radial artery catheter in 13 cases and by oscillometry (Dinamap, Critikon) in two cases. Heart rate and respiratory rate were measured from chest electrodes. Muscle tone was documented using a modification of the Dubowitz neurological assessment. ${ }^{20}$ Blood was taken for measurement of serum $\mathrm{Mg}^{2+}$ at 0 , one, three, six, 12, and 24 hours in the routine clinical chemistry laboratories. The evaluation of $\mathrm{MgSO}_{4}$ as a potential cerebral protective agent has been approved by the local research ethics committee in each participating centre.

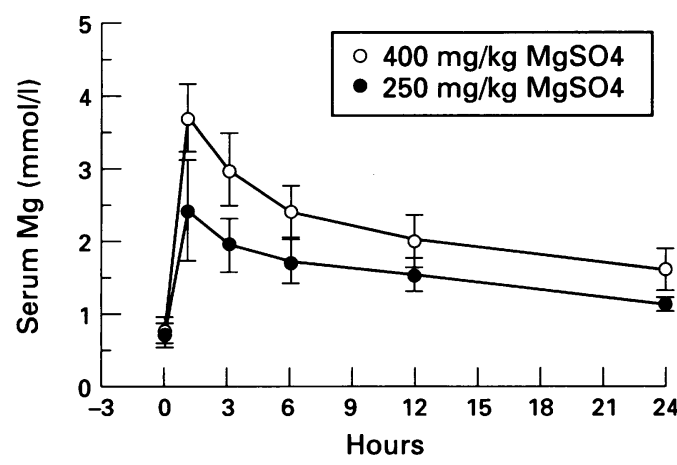

Figure 1 Serum $\mathrm{Mg}^{++}$concentrations (mean \pm standard deviation) in seven infants receiving $400 \mathrm{mg} / \mathrm{kg} \mathrm{MgSO}$ and eight infants receiving $250 \mathrm{mg} / \mathrm{kg} \mathrm{MgSO}_{4}$ with birth asphyxia.

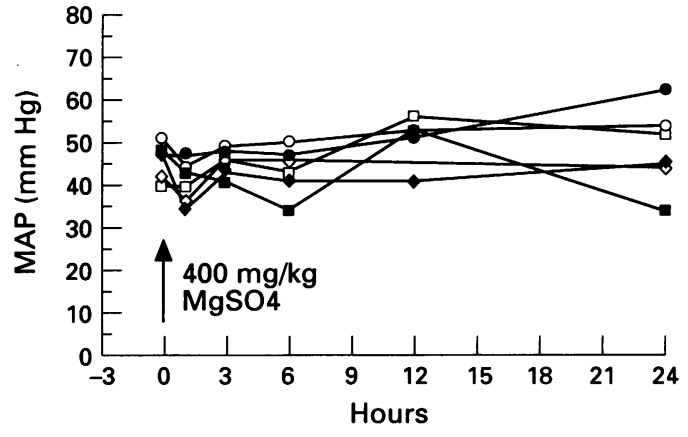

Figure 2 Mean arterial pressure $(M A P)$ in each of the seven infants who received $400 \mathrm{mg} / \mathrm{kg} \mathrm{MgSO} 4$.

\section{Results}

Seven infants received $400 \mathrm{mg} / \mathrm{kg} \mathrm{MgSO}_{4}$ and eight received $250 \mathrm{mg} / \mathrm{kg} \mathrm{MgSO}_{4}$. Figure 1 shows the serum $\mathrm{Mg}^{2+}$ concentrations in the seven infants who received $400 \mathrm{mg} / \mathrm{kg}$. The mean serum $\mathrm{Mg}^{2+}$ rose from $0.79 \mathrm{mmol} / 1$ to $3.6 \mathrm{mmol} / \mathrm{l}$ at one hour, $2.0 \mathrm{mmol} / \mathrm{l}$ at 12 hours, and remained increased at $1.6 \mathrm{mmol} / \mathrm{l}$ after 24 hours. MAP (fig 2) fell in the first hour by an average of $6 \mathrm{~mm} \mathrm{Hg}(13 \%)(P<0.05$ by paired $t$ test). The reduction in MAP was noted as soon as the $\mathrm{MgSO}_{4}$ infusion had been given. In the most seriously ill infant, already requiring an infusion of $12 \mu \mathrm{g} / \mathrm{kg} / \mathrm{minute}$ dopamine to hold MAP over $40 \mathrm{~mm} \mathrm{Hg}, 400 \mathrm{mg} / \mathrm{kg} \mathrm{MgSO}_{4}$ was associated with a decrease in the MAP from 48 to $33 \mathrm{~mm} \mathrm{Hg} 30$ minutes after the start of the $\mathrm{MgSO}_{4}$ infusion; the dopamine infusion was immediately increased to $20 \mu \mathrm{g} / \mathrm{kg} /$ minute (fig 3). At 45 minutes (five minutes after the $\mathrm{MgSO}_{4}$ infusion had finished) MAP had fallen to $25 \mathrm{~mm} \mathrm{Hg}$ but rose to $43 \mathrm{~mm} \mathrm{Hg}$ at 60 minutes when the increased rate of dopamine infusion was maintained.

Mean heart rate fell by 10 beats a minute but this difference did not reach significance. All the infants receiving $400 \mathrm{mg} / \mathrm{kg}$ were intubated and mechanically ventilated before receiving the $\mathrm{MgSO}_{4}$ and those that were breathing spontaneously ceased to breathe spontaneously for three to six hours. Two of the infants were profoundly hypotonic before the $\mathrm{MgSO}_{4}$ infusion and there was no change in tone

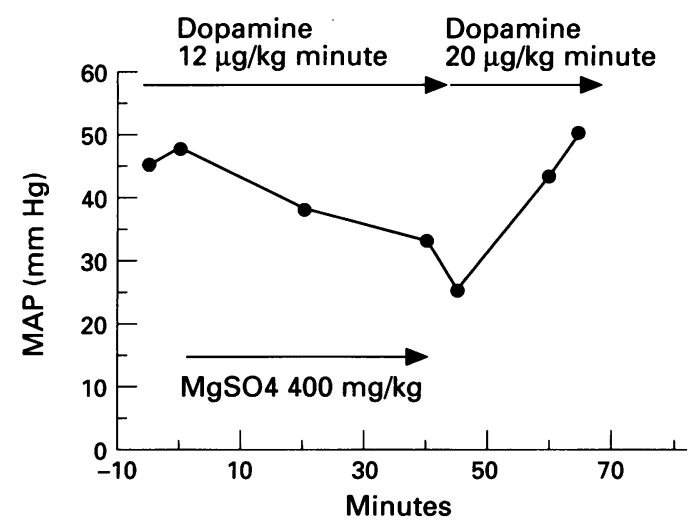

Figure 3 Mean arterial pressure $(M A P)$ in one infant who received $400 \mathrm{mg} / \mathrm{kg} \mathrm{MgSO}_{4}$. The infant was already dependent on a dopamine infusion before the magnesium was started and the rate of dopamine infusion was increased because of the falling MAP. The nadir of MAP occurred five minutes after the magnesium infusion finished. 
afterwards. The other five had varying degrees of tone which diminished for three to 12 hours after the $\mathrm{MgSO}_{4}$ infusion. The EEG and CFM recordings before the magnesium infusion varied from extremely low background amplitude, or burst-suppression, to continuous normal amplitude activity but there was no change in amplitude or continuity after the $\mathrm{MgSO}_{4}$ infusion.

The changes in serum $\mathrm{Mg}^{2+}$ after an infusion of $250 \mathrm{mg} / \mathrm{kg}$ are shown in fig 1 . Serum $\mathrm{Mg}^{2+}$ rose from a mean of $0.71 \mathrm{mmol} / 1$ to 2.42 $\mathrm{mmol} / \mathrm{l}$ at one hour, $1.52 \mathrm{mmol} / 1$ at 12 hours, and $1.12 \mathrm{mmol} / \mathrm{l}$ at 24 hours. There was no significant change in MAP (fig 4), heart rate, tone, or EEG. Four out of eight infants were already intubated and ventilated before the $\mathrm{MgSO}_{4}$ infusion. One of the infants who was not intubated became transiently desaturated (oxygen saturation by pulse oximeter was 60-70\%) with shallow respiration after receiving $250 \mathrm{mg} / \mathrm{kg}$ and required five minutes of oxygen by face mask and bag to restore normal saturation. This infant did not require intubation and breathed satisfactorily later. The other three infants who were not intubated breathed satisfactorily throughout.

Using standard pharmacokinetic methods, ${ }^{21}$ semilogarithmic plots of serum concentration $v$ time indicate that the elimination of $\mathbf{M g}^{2+}$ displays biphasic kinetics. The population mean half lives of the terminal elimination phases $\left(t \frac{1}{2} \beta\right)$ were 28.06 hours and 27.61 hours, respectively, for the low and high dose regimens.

Two infants had lumbar punctures as part of standard procedure and cerebral spinal fluid $\mathrm{Mg}^{2+}$ was $1.43 \mathrm{mmol} / \mathrm{l}$ about three hours after $\mathrm{MgSO}_{4}$ infusion ( $v 2.15$ in serum) and 1.71 $\mathrm{mmol} / \mathrm{l}$ about 10.5 hours after the infusion $(v$ $1.91 \mathrm{mmol} / \mathrm{l}$ in serum).

\section{Discussion}

The vasodilator properties of magnesium sulphate have been used extensively for the treatment of pre-eclampsia ${ }^{14}$ and, to a limited extent, persistent pulmonary hypertension in the newborn. ${ }^{22}$ The drop in blood pressure (mean $6 \mathrm{~mm} \mathrm{Hg}$ or $13 \%$ at one hour) noted with the higher dose can be explained on this basis. The drop in MAP from 48 to $25 \mathrm{~mm} \mathrm{Hg}$ in one infant, necessitating an immediate increase in the dopamine infusion rate, indicates that hypotension after high dose

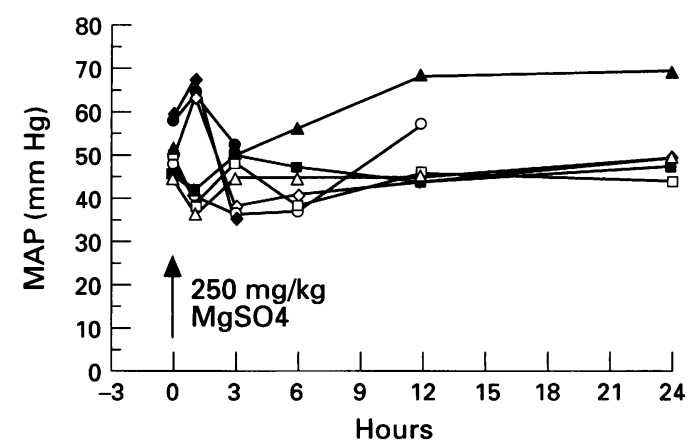

Figure 4 Mean arterial pressure in eight infants receiving $250 \mathrm{mg} / \mathrm{kg} \mathrm{MgSO}$.
$\mathrm{Mg}^{2+}$ could have serious consequences if monitoring is not good and immediate corrective action is not taken. There was no significant reduction in MAP (compared with the pretreatment level) at three hours or later. There was no significant drop in MAP at one hour in the infants receiving $250 \mathrm{mg} / \mathrm{kg}$ $\mathrm{MgSO}_{4}$.

The neuromuscular blocking effect of $\mathrm{Mg}^{2+}$ was noted in the infants receiving $400 \mathrm{mg} / \mathrm{kg}$ where spontaneous respiration was abolished for several hours and muscle tone was decreased. The lack of change in the EEG is evidence that hypotonia does not have a central role. Although muscle tone did not show an objective decrease in the infants receiving $250 \mathrm{mg} / \mathrm{kg}$, the transient respiratory depression in one unintubated infant was most likely the result of partial neuromuscular blockade.

On the basis of limited data, cerebrospinal $\mathrm{Mg}^{2+}$ concentrations were lower than those in serum and the cerebrospinal fluid:serum ratio was lower with earlier rather than later sampling. This apparent delay in $\mathbf{M g}^{2+}$ transfer could be explained by limited capacity of the active pump across the blood-brain barrier. The turnover of the cerebrospinal fluid reservoir might also be slow enough to prevent a rapid rise in $\mathrm{Mg}^{2+}$. Clearly any cerebral protective effect of $\mathrm{Mg}^{2+}$ is dependent on its penetrating the brain rapidly.

We conclude that the use of $400 \mathrm{mg} / \mathrm{kg}$ $\mathrm{MgSO}_{4}$ in asphyxiated infants is associated with an unacceptable risk of hypotension. Hypotension after asphyxia would be particularly hazardous in situations with poor staffing or inadequate monitoring equipment. The lower dose of $\mathrm{MgSO}_{4}(250 \mathrm{mg} / \mathrm{kg})$ was not associated with hypotension but may cause respiratory depression. Thus we recommend that respiration should be carefully assessed and monitored in infants before this dose is given. If there is any doubt about the adequacy of spontaneous respiration, intubation and ventilation before the first dose of $\mathrm{MgSO}_{4}$ would be advisable. As the blood pressure response to $\mathrm{MgSO}_{4}$ varied considerably among infants, continuous or frequent blood pressure measurement is necessary as well as the availability of dopamine. Secondary injury to the posthypoxic neonatal brain can occur over a period that may last as long as 72 hours. ${ }^{23}$ If $\mathrm{Mg}^{2+}$ were to be evaluated as a neuroprotective agent in severely asphyxiated infants a dosing regimen aimed at maintaining increased concentrations for 72 hours would be necessary. Based on the estimates of a plasma half life of $\mathrm{MgSO}_{4}$ reported here, an effective dosing regimen comprises a loading dose of $250 \mathrm{mg} / \mathrm{kg}$, followed by two further infusions of $125 \mathrm{mg} / \mathrm{kg}$ at 24 hours and 48 hours. This would ensure that plasma concentrations of $\mathrm{Mg}^{2+}$ were maintained in the range 1.2 to $2.5 \mathrm{mmol} / \mathrm{l}^{24}$

This study was supported by the Laerdal Foundation for Acute Medicine and the Norwegian Association for Public Health.

1 Ergander U, Eriksson M, Zetterström R. Severe neonatal asphyxia: incidence and prediction of outcome in the 
Stockholm area. Acta Paediatrica Scandinavica 1983; 72: $321-5$.

2 Nelson KB, Ellenberg JH. Apgar scores as predictors of chronic neurological disability. Pediatrics 1981 ; 68: 36-44

3 Levene MI, Sands C, Grindulis H, Moore JR. Comparison of two methods of predicting outcome in perinatal asphyxia Lancet 1986; i: 67-9.

4 Peliowski A, Finer NN. Birth asphyxia in the term infant. In: Sinclair JC, Bracken MB, eds. Effective care of the newborn infant. Oxford: Oxford University Press, 1992: 249-80

5 Robertson CM, Finer NN. Term infants with hypoxicischaemic encephalopathy: outcome at 3.5 years. Dev Med Child Neurol 1985; 27: 473-84.

6 Robertson CM, Finer NN, Grace MG. School performance of survivors of neonatal encephalopathy associated with birth asphyxia at term. Pediatrics 1989; 114: 753-60.

7 Benveniste H, Drejer J, Schousboe A, Diemer NH. Elevation of the extracellular concentrations of glutamate and aspartate in rat hippocampus during transient cerebral ischaemia monitored by intracerebral microdialysis. bral ischaemia monitored by
$\mathcal{F}$ Neurochem $1984 ; 43: 1369$

8 McDonald JW, Johnson MV, Young AB. Differential ontogenic development of three receptors comprising the NMDA receptor/channel complex in the rat hippocampus. Exp Neurol 1990; 110: 237-47.

9 Insel TR, Miller LP, Gelhard RE. The ontogeny of excitatory amino acid receptors in rat forebrain 1 . N-Methyl-D-aspartate and quisqualate receptors. Neuroscience 1990; 35: 31-43.

10 McDonald JW, Roeser NF, Silverstein FS, Johnston MV. Quantitative assessment of neuroprotection against NMDA-induced brain injury. Exp Neurol 1989; 106: 289-96.

11 Hattori H, Morin AM, Schwartz PH. Posthypoxic treatment with MK-801 reduces hypoxic-ischaemic damage in the neonatal rat. Neurology 1989; 39: 713-8.

12 McDonald JW, Silverstein FS, Johnson MV. Magnesium reduces N-methyl-D-aspartate (NMDA)-mediated brain injury in perinatal rats. Neurosci Lett 1990; 109: 234-8.
13 Thordstein $M$, Bågenholm $\mathrm{R}$, Thiringer $\mathrm{K}$, Kjellmer I Scavengers of free radicals in combination with magnesium ameliorate perinatal hypoxic-ischaemic brain damage in the rat. Ped Res 1993; 34: 23-6.

14 Cotton DB, Janusz CA, Berman RF. Anticonvulsant effects of magnesium sulphate on hippocampal seizures: therapeutic implications in pre-eclampsia. Am $\mathcal{F}$ Obstet Gynecol 1992; 166: 1127-36

15 Altura BT, Altura BM. Withdrawal of magnesium causes vasospasm while elevated magnesium produces relaxation of tone in cerebral arteries. Neurosci Lett 1980; 20: 323-7.

16 Lipsitz PJ. The clinical and biochemical effects of exces magnesium in the newborn. Pediatrics 1971; 47: 501-9. 17 Oppelt WW, MacIntyre I, Rall DP. Magnesium exchange 205: 959-62.

18 Kato G, Somjen GG. Effects of microiontophoretic administration of magnesium and calcium on neurones in the
central nervous system of cats. $\mathcal{F}$ Neurobiol $1969 ; 2: 181-5$.

19 Mordes JP, Wacker WC. Excess magnesium. Pharmacol Rev 1978; 29: 273-300.

20 Dubowitz LMS, Dubowitz V. The neurological assessment of the pre-term and full-term infant. Clinics in developmental medicine. No 79. London: SIMP/Heinemann, 1981

21 Rowland M, Tozer TN. Clinical pharmacokinetics: concepts and applications. 2nd edn. London: Lea $\&$ Febinger, 1989: 17-32

22 Abu-Osba Y, Galal O, Manastra K, Rejjal A. Treatment of severe persistent pulmonary hypertension of the newborn with magnesium sulphate. Arch Dis Child 1992; 67: 31-3.

23 Roth SC, Edwards AD, Cady EB, Delpy DT, Wyatt JS, Azzopardi D, et al. Relation between cerebral oxidative metabolism following birth asphyxia and neurodevelopmental outcome and brain growth at one year. Dev Med Child Neurol 1992; 34: 285-95.

24 Rowland M, Tozer TN. Clinical pharmacokinetics: concepts and applications. 2nd edn. London: Less \& Febinger, 1989: 78-100. 